\title{
The Literature Review of Brand Equity and Consumer Buying Behaviour: 1980 2014
}

\author{
Le Wang \\ School of Management \\ Bohai University \\ Jinzhou China \\ lewang1982@163.com \\ Benjamin Addei-Duah \\ School of Management \\ Bohai University \\ Jinzhou China \\ bengycris@yahoo.com
}

\author{
Wanliang Dai \\ School of Management \\ Bohai University \\ Jinzhou China \\ yi4955@sina.com \\ Xiaoshu Wang \\ Internship and Employment Office \\ Bohai University \\ Jinzhou China \\ xiaoshu_1984@126.com
}

\begin{abstract}
This literature review presents an overview of the definition of brand, important roles of brand, followed by the characteristics of successful brands, consumer buying behavior and finally the models of consumer behavior. Brands are so important that they are regarded as the equity to a firm. Brand equity can be divided into four dimensions, including brand awareness, perceived quality, brand loyalty and brand associations. The study of consumer buying behaviour is of utmost importance in a number of aspects. First of all, consumer behaviour can influence the economic health of a nation. Second, through understanding the reasons for consumers to buy the products and their buying habits, the firms can make use of such information to devise corresponding marketing strategies in response to the consumers' needs. Only by understanding the consumer purchasing behaviour can the products or brands be developed in a right way.
\end{abstract}

Keywords-brand research; brand characteristics; consumer buying behaviour; consumer preferences; brand loyalty

\section{DEFINITION OF BRAND}

One definition for a brand has been offered in the Journal of Marketing Management by Professor Peter Doyle of Warwick University: "A name, symbol, design, or some combination which identifies the product of a particular organization as having a substantial, differentiated advantage" (O'Malley, 1991). Another definition by Kapferer (2004) says that a brand is a set of mental associations, held by the customer, which add to the perceived value of a product or service. These associations should be unique (exclusive), strong (salient), and positive (desirable). To many, a brand suggests the best choice, while others see a brand as something the customer knows and will react to. Despite the formal definition, the purpose of branding is essentially to build the product's image (Cleary, 1981). This image will influence the perceived worth of the product and will increase the brand's value to the customer, leading to brand loyalty (The Economist, 2007).

\section{THE IMPORTANT ROLES OF BRAND}

Brand is a name in every consumeres mind (Mooij, 1998) and it is characterized by a noticeable name or symbol which can differentiate the goods and services from the rivals ${ }^{\text {ee }}$ (Aaker, 1991; Keller, 1998). In addition to a specific brand name, a brand is also composed of products, packaging, promotion, advertising, as well as its overall presentation (Murphy, 1998).

From the consumers ${ }^{\text {ec }}$ perspective, brand is a guarantor of reliability and quality in consumer products (Roman et al., 2005). Added to this, consumers would like to buy and use brand-name products with a view to highlight their personality in different situational contexts (Aaker, 1999; Fennis and Pruyn, 2006).

Nowadays, consumers have a wide range of choice to choose from when they enter a shop. It is found that consumers $^{\text {ee }}$ emotions are one of the major determinants which affect their buying behaviour (Berry, 2000). According to a research conducted by Freeride Media LLC (1998) on shopping habits, nearly one-fourth of the respondents are likely to impulse-buy clothes and accessories. When deciding which products to purchase, consumers would have their preferences, which are developed in accordance with their perceptions towards the brand. Successful branding could make consumers aware of the presence of the brand and hence could increase the chance of buying the company's products and services (Doyle, 1999).

\section{THE CHARACTERISTICS OF SUCCESSFUl BRANDS}

A brand can be an everlasting and lucrative asset as long as it is maintained in a good manner that can continue satisfying consumerse ${ }^{\text {ee }}$ needs (Batchelor, 1998; Murphy, 1998). Although successful brands can be totally different in nature, they share something in common, for instances well-priced products and consistent quality (Murphy, 1998). As mentioned by Levitt (1983), there are four elements for building a successful brand, namely tangible product, basic brand, augmented brand, potential brand. 


\section{A. Brand Equity}

The term ,brand equity ${ }^{\text {ee }}$ refers to a set of assets and liabilities associated with a brand, including its name and symbol, which could impose beneficial or detrimental effects on the values arising from the products or services (Aaker, 1991; Yasin et al., 2007). This bring to bear the argument that, since brand equity draws on the imperfect and asymmetrical nature of markets (Erdem and Swait 1998), economic agents are required to transmit information about their specific characteristics by means of signals (Christodoulides and Chernatony, 2009).

Added to this, Keller (1998) points out that brand equity signifies the unique marketing effects imposed on the brand. Concerning the positive side of brand equity, it happens when consumers are willing to pay more for the same level of quality just because of the attractiveness of the name attached to the product (Bello and Holbrook, 1995). However, brand equity could be ruined if it is not properly managed. For instance, poor product quality and customer services could adversely affect the brand image, giving rise to a reduction in sales volume. Just as was argued by Christodoulides and Chernatony (2009), brand equity is a complex and multi-faceted concept and as such, it needs to be captured through a set of measures rather than a single measure.

One of the quintessential examples regarding brand as a kind of equity is the imposition of laws to protect intellectual property (Murphy, 1998). In countries with well-established legal system, the values of brands have been recognized to both the consumers and producers. In order to combat piracy, many countries have set up laws to protect trademarks, patents, designs as well as copyright. In addition, brand is also a tradable product with measurable financial value (Murphy, 1998). The measures selected should be aligned with the brands vision (Davis, 2000). It is not uncommon to find some familiar brands listed on the stock markets in which they could be bought or sold. Brands like Marks and Spencer, Vodafone and Tesco are all listed on the FTSE 100 index (London Stock Exchange, 2007). It is found that the volatility of stock market could affect consumers ${ }^{\text {ee }}$ purchasing mood, not to mention the growth or declines of retail sales (Blackwell, 2002). This is supported by the fact that brand equity depends on the number of people with regular purchase (Aaker, 1996).

The above examples highlight the values of brand equity for both consumers and the firm. For the consumers, brand equity could provide them with information about the brand which influences their confidence during the purchasing process. There is a high propensity for consumers with good perceptions to buy from the same shop again than those with poor perceptions. Past purchasing experiences and familiarity with the brand could be attributable to the perceptions generated from the consumers (Aaker, 1991). As for the firm, brand equity could also be a source for the firm to generate cash flow. For instance, the merger between adidas and Reebok in 2005 not only increased their market share so as to compete with Nike in the US sports apparel market, but also attracted more people to invest in the bigger company with high potential (Business Week, 2005).

Besides, brand equity could also allow higher margins through premium pricing and reduced reliance upon promotional activities (Aaker, 1991). Owning to the positive image, consumers no longer focus on the shortterm promotion but the brand on the whole. Brand equity is a broad concept which can be further subdivided into four main areas, namely brand loyalty, name awareness, perceived quality and brand associations (Aaker, 1991; Keller, 1998).

\section{B. Brand Awareness}

Brand awareness is one of major determinants of brand equity. It refers to the ability of a potential consumer to recall and recognize the brand, linking the brand with its corresponding product class (Aaker, 1991). The level of brand awareness lies in a continuum, with brand recognition being the lowest level and the first named brand with unaided recall being the highest level. It is important for the potential consumers to be aware of a product so that it can become one of the purchasing choices. This is due to the fact that the product needs to enter the awareness set before it comes to the consideration. This is seen as very important due $t$ the increasing demand for counterfeit branded products (Bian and Moutinho, 2009).

\section{Perceived Quality}

Another important attribute to brand equity is perceived quality. It is defined as the customer's perception of the overall quality or superiority of a product or service (Aaker, 1991; Keller, 1998; Yasin, 2007). Since it is a kind of intangible, overall feeling towards a brand, it is subjective in nature and hence the knowledge of actual detailed product specifications could have little correlation with the perceived quality. Perceived quality of a brand could help generate values by providing a pivotal reasonto-buy, differentiating the position of a brand, charging premium price, motivating channel members to perform well and also introducing extensions into new brand categories (Aaker, 1991). Proper branding can result in higher sales of not only one product, but on other products associated with that brand. For example, if customers loves Pillsbury biscuits and trust the brand, he or she is more likely to try other products offered by the company such as chocolate chip cookies.

Brand is the personality that identifies a product, service or company (name, term, sign, symbol, or design, or combination of them) and how it relates to key constituencies: customers, staff, partners, investors etc. Some people distinguish the psychological aspect, brand associations like thoughts, feelings, perceptions, images, experiences, beliefs, attitudes, and so on that become linked to the brand, of a brand from the experiential aspect.

The experiential aspect consists of the sum of all points of contact with the brand and is known as the brand experience. The brand experience is a brand's action perceived by a person. The psychological aspect, sometimes referred to as the brand image, is a symbolic construct created within the minds of people, consisting of all the information and expectations associated with a product, service or the company(ies) providing them.

In addition, it is found that perceived quality is of utmost importance in determining brand loyalty as well as repeat purchase (Delong et al., 2004). Nevertheless, it is becoming more difficult to obtain satisfactory level of perceived quality owing to the fact that fast and continuous 
product advancement has already strengthened consumers ${ }^{\text {ee }}$ expectations on product quality (Sherman, 1992).

Similar to brand awareness, perceived quality is determined by a number of factors. To be more specific, perceived quality can further be classified into product quality and service quality. Regarding product quality, there are seven dimensions which affect the consumerse perception, namely performance, features, conformance with specifications, reliability, durability, serviceability as well as fit and finish. Service quality, on the other hand, is judged by its corresponding tangibles, reliability, competence, responsiveness and empathy (Aaker, 1991). In addition to the aforementioned dimensions, the countryof-origin of a product is found to affect its perceived quality (Khachaturian and Morganosky, 1990) and also the perceptions towards the purchased value (Ahmed and d'eeAstou, 1993).

\section{Consumer Preferences}

Consumer preference for a product can make or break a company. If consumers generally like a product, it can stay around for years and sell millions of copies. However, if consumers do not like a product, it could disappear very quickly if the company cannot figure out how to fix the problem. The underlying assumption is that consumer preference for the characteristics of a product can help identify relationships with consumer purchase intent.

As mentioned by Srikatanyoo and Gnoth (2002), consumers are inclined to develop stereotypical beliefs about the products from particular countries. Hence, consumers could have their preferences for products made from one country over another (Papadopoulos et al., 1991). Moreover, price is one of the important cues to evaluate perceived quality (Aaker, 1991). It is found that price is more relevant in judging the perceived quality of a product given that a person lacks the ability to evaluate the quality of a product.

\section{E. Brand Loyalty}

Brand loyalty is one of the core components of brand equity and also positively and directly affected by brand equity (Atilgan et al., 2005). Under the influence of brand loyalty, consumers continue to buy the brand, regardless of the superior features, prices and convenience owned by its competitors (Aaker, 1991). The more loyal the consumers are towards the brand, the less vulnerable the customer base would be. Nam et al. (2011) argued that the effect of physical quality and lifestyle congruence on brand loyalty is fully mediated by consumer satisfaction. This goes to support the definition given by Rai \& Medha, (2013, p. $141)$ on brand loyalty which simply defines loyalty as "attitude and behavior".

Based on the practice that repeat buying is one of the indicators for brand loyalty, Keller (1998), however, challenges that such measure may not be totally accurate. This is due to the fact that some consumers make habitual purchase towards a particular brand just because of its prominence in stock and effective promotions.

For many companies, having loyal customers is a kind of blessing. Brand loyalty is regarded as valuable asset under different circumstances. First, it can help reduce the marketing costs of doing business (Aaker, 1991). Loyal customers confer to a higher possibility of repeat purchases and it is less costly to keep customers than to get new ones. Second, loyalty to a brand can enhance trade leverage. Some consumers with strong affiliation to one brand would switch to the shop in which a designated brand is sold. Third, loyal customers could influence the others to purchase the brand. This is typically true when the product concerned is somewhat risky.

In this case, consumers are assured to buy the product if they have some friends or relatives who recommend the same model of product. This suggests why word-of-mouth communication is one of the most powerful tools in the marketplace (Henricks, 1998; Marney, 1995; Silverman, 1997; Bansal and Voyer, 2000).

Consumers usually depend on informal, as well as personal communication sources in making purchasing decision rather than more formal and organizational advertising campaigns (Bansal and Voyer, 2000). Finally, brand loyalty can help provide ample time for the firm to response to competitors ${ }^{\text {ee }}$ newly launched products. Hence, the firm could make good use of the time lapse to develop more superior products in order to compete with its rivals.

Due to the values obtained from brand loyalty, many firms would devise different strategies to maintain and enhance the loyalty from customers. According to Aaker (1991), it is important to treat the customer with respect in order to keep them loyal. Moreover, customer satisfaction level needs to be properly managed through conducting consumer research. Customers can also be rewarded for their loyalty towards the firms so that they will continue to buy the products.

However, in cases where customers intends to switch that is their willingness not to buy the product or service from the company and their willingness to buy the product within the same category from another company (Kwong and Candinegara, 2014). It can be argued that this intention has negative impact on loyalty since customers are usually considered loyal when their switching intentions are low.

\section{F. Brand Association}

The last dimension for brand equity is brand association. It is defined as the specific linkage between the memory and the brand (Aaker, 1991). Keller (1998) and Yasin et al. (2007) further note that equity of a brand is largely supported by consumerse ${ }^{e e}$ associations towards the brand, which contribute to a specific brand image Brand association is such a complicated concept that connects to one another, consisting of multiple ideas, episodes, examples, and facts that create a brand knowledge network (Yoo et al., 2000).

In addition to the tangible products, the intangible qualities, for instances innovativeness and distinctiveness are also taken into account as brand associations. Keller (1993, 1998) further divides brand associations into three categories, namely;

Attributes: Attributes refer to the specific characteristics a product has. Attributes can be further categorized into product-related attributes as well as nonproduct related attributes. For product-related attributes, the overall features of the product or service are concerned. As for non-product related attributes, price information, packaging, user imagery as well as usage imagery are to be considered.

Benefits: Benefits are another category in brand associations. They can be classified into functional, 
experimental and symbolic. Function benefits signify the physical or basic advantages a brand may have. For experimental benefits, they are related to consumerse emotional feelings. Symbolic benefits, on the other hand, refer to the signal effect that a brand may impose on the consumers. Signal effect is determined by the image of consumers and also the personality of the brand. Consumers are attracted by the signal when they purchase a product in a particular brand.

Attitudes: attitudes are regarded as the consumers ${ }^{\text {ee }}$ overall assessments towards a brand. They incorporate summary evaluations of information which represent how consumers feel in a long run, lying in a continuum from positive to negative (Gabbott and Hogg, 1998). Different brands have different associations to their prospective customers. Such kind of associations can provide bases for them to make purchase decisions and even become loyal to the brand (Aaker, 1991).

All consumers have a degree of emotional preference toward certain companies or brands (Hyun and Han, 2012) and usually rely on their existing brand attitude when making decisions regarding the new product. Kim et al., (2011) defined brand attitude as an individual's internal evaluation of an object such as a branded product, and suggested that attitudes are often stable and enduring predispositions to behavior.

Associations towards a brand can create value for the firm and so its customers in a number of ways. First of all, they help the customers to process or retrieve information (Keller, 1998). Customers are sometimes forgetful and associations towards a brand serve as a brief summary for the customers to make their purchasing decision. Associations can also be used to trigger the customers to recall their past experiences, making the customers remember the brand by heart. Second, brand associations can differentiate one brand from another. It is about brand positioning that a well-positioned brand will find it hard to be attacked by its competitors due to its uniqueness. This can make the brand unbeatable but it is quite difficult to achieve since consumer taste changes quite rapidly.

\section{CONSUMER BUYING BEHAVIOUR}

Many people do consume a wide range of products every day, from basic necessities to high valued collectables. Owing to the proliferation of products in the market, such phenomenon is one of the most interesting and hence heavily investigated topics in the marketing field. As mentioned by Schiffman and Kanuk (2000), consumer behaviour is about how people make their decisions on personal or household products with the use of their available resources such as time, money and effort. Gabbott and Hogg (1998) and Blackwell et al. (2006) further provide a holistic view that defines consumer behaviour as the activities and the processes in which individuals or groups choose, buy, use or dispose the products, services, ideas or experiences. However, it can also be argued that consumer behaviour engages in the thoughts and feelings that people experience and the actions they perform in the consumption process (Nguyen, 2014).

The study of consumer buying behaviour is of utmost importance in a number of aspects. First of all, consumer behaviour can influence the economic health of a nation
(Blackwell et al., 2006). Consumers would have their preferences in purchasing products from specific retailers and hence the remaining retailers are selected using the rule of ,survival of the fittest ${ }^{\mathrm{e}}$. Therefore, consumers decisions can provide a clue for which industry to survive, which companies to succeed, and also which products to excel.

Second, through understanding the reasons for consumers to buy the products and their buying habits, the firms can make use of such information to devise corresponding marketing strategies in response to the consumers $^{\text {ee }}$ needs (Blackwell et al., 2006). Moreover, present consumer behaviour studies regard consumers as important determinants of organizational success and it is found that the most successful organizations are customercentric (Blackwell et al., 2006). The notion ,the consumer is kingee should be deep-rooted in every business people $\mathrm{s}$ mind that they should try to please these kings using their innovative methods.

\section{MODEls OF CONSUMER BEHAVIOR}

Several models are developed with a view to provide explanations for the consumer buying behaviours. Although they vary in form of presentation, most of them are composed of stages such as pre-purchase, purchase and post-purchase (Hoyer and Maclnnis, 2001; Rayport and Jaworski, 2003). Blackwell et al. (2001) define consumer behaviour as a summation of acquisition, consumption and disposal of products or services. However, such definition falls short of the continuity of the processes. Based on this loophole, Arnoud et al. (2004) further propose the circle of consumption that recognize purchasing processes as a loop, comprising acquisition of goods and services, consumption, as well as disposal of used goods. As far as the consumer decision process model is concerned, consumers need to go through seven steps before reaching their final decisions. These seven steps include; need of recognition, search for information, pre-purchase, evaluation and purchase, consumption, post-consumption evaluation, divestment (Blackwell et al., 2006).

Rayport and Jaworski (2003) propose a similar model with slight differences regarding the terms used. Blackwell et al. (2006) add that most consumer research would primarily base on these seven stages and how different elements affect each stage of consumers ${ }^{\text {ee }}$ decisions, regardless of the different terms and consolidation of stages.

Stage One is need recognition which occurs when an individual is aware of a difference between their perception and the actual satisfaction level (Solomon et al., 2006). The buying process is initiated when people recognize their unsatisfied need (Levy and Weitz, 1992). There are two kinds of needs, namely functional needs and psychological needs. Functional needs are related to the performance of the product whereas psychological needs are intrinsically obtained when customers feel contented with shopping or owning a product which they long for.

Stage Two is the search of information. The length and depth of search vary for different customers and depend on variables like personality, social class, income, size of purchase, past experiences, prior brand perceptions (Moorthy et al., 1997), as well as customer satisfaction. As mentioned by Solomon et al. (2006), search of information 
can further be divided into pre-purchase search and ongoing search. Pre-purchase search is initiated when consumers recognize a need and hence look for more information from the marketplace. Ongoing search, on the other hand, is more likely to be based on personal interest on a particular brand. Customers pursuing this kind of search would like to obtain the most updated information about the designated brand.

Stage Three comes to the pre-purchase evaluation that consumers compare between different products and brands to make a purchasing decision. In this stage, consumers pay particular attention to the attributes which are most relevant to their needs (Kolter et al., 2005). Attributes like quantity, size, quality and price are commonly used to judge a brand by customers. Any changes in these attributes can affect consumer decisions on brand or product choices (Blackwell et al., 2006). According to Porter (2004), firms can create value by providing lower price or unique offers to the customers so as to excel their competitive advantages over the others.

Stage Four refers to the purchase decisions made by the consumers after evaluating the offers from different retailers. As stated by Blackwell et al. (2006), there are two phases contributing to the decision making processes, including retailer and in-store selection. Retailer selection is made by judging which retailers to buy after investigating the attributes from the previous stage whereas in-store selection is affected by the selling skills of salesperson, visual displays inside the shops, as well as point-of-purchase advertising. In addition to in-store purchase, Rayport and Jaworski (2003) further point out the significant impact of internet on consumer purchasing decision. As pointed out by Dholakia and Uusitalo (2002), this new kind of non-shop retailing format has begun replacing the fairly established catalogue and TV shopping and its development is rapid albeit it is more recently found in comparison with the existing non-shop retailing modes.

Stage Five, Stage Six and Stage Seven are under the category of the post-purchase stage. In stage five, customers begin consuming the products whereas in stage six, customers evaluate the consumption process. This gives rise to satisfaction when consumers ${ }^{\text {ee }}$ expectations are higher than the perceived performance and vice versa (Blackwell et al., 2006).

Last but not least, stage seven comes to divestment, in which consumers dispose or recycle the products and at the same time. The firms need to think about the possibility of remarketing. This stage is crucial since customers could be possible to make repeat purchases provided that they are satisfied with the aforementioned stages (Rayport and Jaworski, 2003).

\section{SUMMARY}

This paper provides a review about the major research and theories regarding the characteristics of successful brands and consumer purchasing behavior. Brands are so important that they are regarded as the equity to a firm.
Brand equity can be divided into four dimensions, including brand awareness, perceived quality, brand loyalty and brand associations. All of them have significant contribution to the brand as equity to the firm. Nowadays, consumers seem to be more aware of the products they buy, and at the same time, products are developed in an unprecedented way.

Only by understanding the consumer purchasing behaviour can the products or brands be developed in a right way. In this research, we would investigate whether the brand image would affect the consumers to purchase products/good is to be investigated. It is hoped that by finding out the relationships of brand awareness, perceived quality, brand loyalty and brand association with the consumer purchasing behavior this will provide useful insights for the development of companies in many countries.

\section{REFERENCES}

[1] L. Aaker, "The malleable self: The role of self-expression in persuasion", Journal of Marketing Research, vol.36, Issue 1,1999, pp. $45-57$

[2] A. Ahmed, A. Astou, "Cross-national evaluation of made-in concept using multiple cues", European Journal of Marketing, vol.27, Issue 7, 1993, pp.39-52.

[3] E. Atilgan, S. Aksoy, S. Akinci, "Determinants of the brand equity: A vertification approach in the beverage industry in Turkey.", Marketing Intelligence \& Planning, vol.23, Issue 3, 2005, pp.237248.

[4] A. Batchelor, "Brands as financial assets", In S. Hart, J. Murphy "Brands:The new wealth creators", London: Macmillan Press, 1998, pp. 95-103.

[5] L. Berry, "Cultivating service brand equity", Journal of the Academy of Marketing Science, vol.28, Issue 1, 2000, pp.128-137.

[6] P. Cleary, "Great American Brands: The Success Formulas That Made Them Famous", New York: Fairchild Publications, 1981.

[7] P. Doyle, "Building successful brands", In L. Butterfield "Excellence in advertising: The IPA guide to best practice", Oxford: Butterworth-Heinemann, 1999, pp. 3-21.

[8] M. Henricks, "Spread the word", Entrepreneur, vol.26, Issue 2, 1998, pp.120-125.

[9] Z. Kwong, I. Candinegara, "Relationship between Brand Experience, Brand Personality, Consumer Satisfaction, and Consumer Loyalty of DSSMF Brand", iBuss Management, vol.2, Issue 2, 2014, pp.89-98.

[10] I. Kim, S. Jeon, S. Hyun, "Chain restaurant patronse well-being perception and dining intentions: The moderating role of involvement", Journal of Contemporary Hospitality Management, vol.24, Issue 3, 2012, pp. 402-429.

[11] D. Duroy, P. Gorse, M. Lejoyeux, "Characteristics of online compulsive buying in Parisian students", Addictive Behaviors, vol. 39, Issue 12, Dec2014, pp.1827-1830.

[12] D. Malley, "Brands mean business", Accountancy, vol.107, 1991, pp.107-108.

[13] S. Sherman, "How to prosper in the value decade", Fortune, Nov 30,1992, pp. 91 .

[14] N. Srikatanyoo, J. Gnoth, "Country image and international tertiary education", Journal of Brand Management, vol.10, Issue 2, 2002, pp.139-148.

[15] M. Yasin, N. Noor, O. Mohamad, "Does image of country-oforigin matter to brand equity?", Journal of Product \& Brand Management, vol.16, Issue 1, 2007, pp.38-48. 